Saudi Journal of Oral and Dental Research

Abbreviated Key Title: Saudi J Oral Dent Res

ISSN 2518-1300 (Print) |ISSN 2518-1297 (Online)

Scholars Middle East Publishers, Dubai, United Arab Emirates

Journal homepage: https://saudijournals.com/sjodr

\title{
"Nutritional Counseling: Perceptions, Perceived Competence, and Barriers to the Provision in the Dental Practice Setting"
}

Dr. K. Srinivasan MDS*

Reader, Department of Pedodontics and Preventive Dentistry CKS Theja Institute of Dental Science and Research, Tirupati, India

DOI: $10.36348 /$ sjodr.2020.v05i02.003

| Received: 20.01.2020 | Accepted: 05.02.2020 | Published: 12.02.2020

*Corresponding author: Dr. K. Srinivasan

\section{Abstract}

Introduction: Human nutrition refers to the provision of essential nutrients necessary to support human life and health. Poor eating habits and lack of nutritional knowledge are crucial public health issues that have serious health implications, through proper dietary education for their patient's, dentists play a significant role in preventing nutritional-related diseases. Aim and Objective: The current study set to evaluate the knowledge, attitude, and practice (KAP) on diet counseling among dental practitioners. Materials and Methods: A cross-sectional study using a pre-tested structured questionnaire written in English, which includes 25 questions based on knowledge of the dental practitioners about diet and nutrition counseling, which were given to 200 participants and the participants asked to respond to each item. Data analysis was performed using SPSS software 21.0 and presented as descriptive statistics and Logistic Regression ( $<<$ $0.05 \%)$. Results: Of the subjects, $78 \%$ agreed that nutrition was a vital component of total health care. However, only $46.8 \%$ of the participants reported that they had received adequate training in diet counseling. Most of the subjects agreed that diet counseling needed to be emphasized in dental education, $28.9 \%$, and only $40 \%$ of the participants expressed their confidence in rendering diet counseling to their patients. Conclusion: The present study concluded that most of the participating subjects had basic knowledge regarding diet and its importance in oral health. Lack of confidence, time, and apprehension about financial reimbursement were three main reasons cited as obstacles for the incorporation of diet counseling in routine clinical practice.

Keywords: Nutrition, Knowledge, Attitude, Diet counseling, private practitioners.

Copyright @ 2020: This is an open-access article distributed under the terms of the Creative Commons Attribution license which permits unrestricted use, distribution, and reproduction in any medium for non-commercial use (NonCommercial, or CC-BY-NC) provided the original author and source are credited.

\section{INTRODUCTION}

An unhealthy diet is identified as a common risk factor threatening both oral and general health [1]. It accounts for many health problems, including Cancers, Cardiovascular diseases, Diabetes, Obesity, Dental caries, and dental erosion [2].

From the dental perspective, dental caries is modulated by diet in several ways, mainly the form and frequency of the consumption of sugars and other fermentable carbohydrates, along with the sequence and combination of food intake and foods' potential to stimulate saliva [1].

Nutrition is vital to human development, growth, and the maintenance of health. Nutritional issues, at the forefront of popular culture, are part of the current wellness and health promotion climate $[3,4]$.
Today, like never before, people are concerned with optimizing their health by acquiring nutritional information and applying it to their daily lives. Nevertheless, with all of the information available in the media, misinformation is also in plenty. Health care professionals frequently neglect inquiries about the patient's nutritional status and offer little guidance in this area [5].

Diet counseling has an essential place in the dental care setting, given the precise relationship between dietary factors and dental caries and the association between obesity, diabetes, and periodontitis [3].

Diet counseling is defined as "a cooperative mode of interaction between the patient and health care provider aimed to assist patients in adopting healthy dietary behaviors associated with improved health outcomes" [6]. 
Moreover, it is an essential step in determining whether nutritional deficiencies/imbalances exist and assessing the need for necessary referrals [9].

Counseling components shown to increase dietary changes include a comprehensive nutritional assessment, family involvement, social support, group counseling, food interaction (cooking, taste testing), goal setting, advice appropriate to patient groups, and anticipatory guidance[1,9].

Anticipatory guidance is "a proactive, developmentally based counseling technique that focuses on the needs of a child at each stage of life." By providing practical and contemporary health information to parents before significant physical, emotional, and Psychological milestones, parents will anticipate impending changes, maximize their child's developmental potential, and identify their child's individual needs[8].

When dietary recommendations are provided, individuals must replace poor nutritional choices for healthy ones. Foods and beverages are not consumed in isolation but rather in patterns and should be considered together [7-8].

When a patient visits a dentist for the first time, a nutritional analysis report gives the patient's oral health status for assessing the prognosis of the treatment. Hence, the dental provider should offer recommendations with suggested strategies to achieve the proposed nutritional modifications [9].

As per the 'Dietary Guidelines for Indians, 2011 of the National Institute of Nutrition (NIN), a balanced diet is "one which provides all the nutrients in required amounts and proper proportions; and unhealthy (junk) foods are those containing little or no proteins, vitamins or minerals but are rich in salt, sugar, fats and are high in energy(calories)" [7].

Hence, the current study was set to assess knowledge, attitude, and practice (KAP) on diet counseling among dental practitioners.

\section{MATERIAL AND METHODS \\ Inclusion Criteria and Exclusion Criteria}

Inclusion Criteria: Participants who were willing to participate in the study.

\section{Exclusion Criteria:}

a) Participants were included in the pilot study.

b) Participants not willing to participate in the study.

c) Physically and mentally disabled person.

Participant recruitment: Registered dental
Pilot study

The quantitative part consisted of administering a pre-tested questionnaire in the English version of among ten dentists in Sept-Oct 2019. As per discussion with them and experts, revision of the questionnaire was carried out to obtain the final version of the survey.

\section{Sample size}

Based on the results of the pilot study, the sample size calculated was 240 dental professionals. It was increased by $25 \%$ to compensate for non-response or incomplete responses of participants. Hence the final sample size for the present study was 300 subjects.

\section{Sampling technique}

Systematic random sampling technique was followed for data collection.

\section{Research Design}

This descriptive, quantitative, cross-sectional, questionnaire-based study was conducted and carried out among Dental practitioners for data collection.

\section{Data Collection}

The survey proforma was prepared with the help of a self-administered structured questionnaire, which was distributed after checking its content and face validity to assess the diet counseling knowledge, attitude, and behavior of the private dental practitioners. The questionnaire had four parts.

A self-administered, structured questionnaire, which included two closed-ended and 23 open-ended questions were framed in consultation with experts in the field.

- The first part of 2 questionnaires was designed to collect personal data, inquiring about, gender and designation.

- The second part comprises eight questions on knowledge of Diet counseling by their patients.

- The third part comprises seven questionnaires on attitudes toward diet counseling by their patients.

- The fourth part comprises ten questionnaires on practice concerning diet counseling by their patients.

Participation in the study was voluntary. A telephone number was also provided for respondents to clear any doubts and confusion regarding the questionnaire. Cutoff date was announced for receipt of the completed questionnaire, after which no further forms were accepted. Questionnaires were distributed to a total of 300 participants. Ten participants were eliminated due to their incomplete nature, yielding a response rate of $96.6 \%(n=290)$. Participants and were asked to respond to each item in the questionnaire by choosing the most appropriate alternative. 
The participants were asked about the balanced diet, nature, type, and frequency of intake, the influence of diet on oral structures, and its effect on oral diseases such as dental caries, periodontal diseases, and malocclusion. Participants were asked about regular recording and counseling of all patients about their diet and nutrition. Some records assess the attitude of the practitioner toward the maintenance of dental records and evidence.

\section{Ethical Consideration}

Consent was obtained from the participants and was assured of the confidentiality, the anonymity of the collected data, and that the resultant information would be used only for the research purposes.

\section{STATISTICAL ANALYSIS}

The reliability and validity of the questionnaire were checked individually for all the three domains, i.e., knowledge, altitude, and practice and was found to be $0.72,0.78$, and 0.69 , respectively. The frequency and percentages of responses were calculated. Much of the material collected was descriptive. Discrete variables were analyzed using a two-tailed Fisher's exact test. P values $<0.05$ were considered statistically significant. Data analyses were performed using SPSS version 21.0.

\section{RESULTS}

The knowledge of the participants toward diet counseling is depicted in Table 2. Of the subjects,
$78.9 \%(n=229)$ agreed that nutrition was an essential component of total health care.

However, only $46.8 \%(n=136)$ of the subjects reported that they had received adequate training in diet counseling. Of the subjects, $15.1 \%(n=44)$ assumed that counseling was synonymous with advice. The majority of the subjects reported rightly that the archcriminal in caries causal on was sucrose $56.2 \%(n=163)$.

Nevertheless, a few subjects, $3.4 \% \quad(n=10)$ answered that it was xylitol that was responsible for caries. The attitudes of the participants toward diet counseling are depicted in Table 3. A large number of subjects, $28.5 \%(n=84)$, agreed with the statement that diet counseling should be emphasized in the dental curriculum.

Nearly half of the subjects $31 \%(n=490)$ agreed with the statement that proper nutrition was essential for oral health. Also, many agreed $30 \%(n=87)$ with the statement that diet counseling was valuable in dental practice too.

The practices of the participants toward diet counseling are depicted in Table 4. Of the subjects, $\mathrm{n}=113(38.9 \%)$ reported that they took dietary history in the routine practice. Also, $41 \%(n=119)$ reported that they gave dietary advice to their patients. Only $40 \%$ $(39 \%)$ of the subjects expressed their confidence in rendering diet counseling to their patients.

Table-1: Social -demographic variables of respondents $(n=290)$

\begin{tabular}{|c|c|c|c|}
\hline \multicolumn{3}{|c|}{ Individual Scenario. } \\
\hline \multicolumn{2}{|c|}{ Variable } & $\begin{array}{c}\text { Response } \\
(\mathbf{n})\end{array}$ & $\begin{array}{c}\text { Frequency } \\
(\mathbf{\%})\end{array}$ \\
\hline \multicolumn{2}{|c|}{ Total no of respondent } & $290 / 300$ & 96.6 \\
\hline \multirow{2}{*}{ Gender } & Males & 99 & 34.1 \\
\cline { 2 - 4 } & Females & 191 & 65.8 \\
\hline Designation & Private practitioners & 290 & 100 \\
\hline
\end{tabular}


Table-2: Distribution of subjects according to the knowledge of Diet Counseling $(n=290)$

\begin{tabular}{|c|c|c|c|c|c|}
\hline \multicolumn{6}{|c|}{ Individual Scenario } \\
\hline Variables & Respondents & $\begin{array}{l}\text { Frequency } \\
\text { (n) }\end{array}$ & $\begin{array}{l}\text { Response } \\
\text { rate } \\
(\%)\end{array}$ & $\begin{array}{l}\text { Mean } \pm \\
\text { SD }\end{array}$ & $\begin{array}{l}\text { Inferential } \\
\text { Statistics }\end{array}$ \\
\hline \multirow{2}{*}{$\begin{array}{c}\text { Nutrition is an essential part of } \\
\text { health care. }\end{array}$} & Yes & 229 & 78.9 & \multirow{2}{*}{$\begin{array}{l}145 \pm \\
118.7\end{array}$} & \multirow{2}{*}{$\begin{array}{l}P<0.222 \\
\quad \mathrm{NS}\end{array}$} \\
\hline & No & 61 & 21 & & \\
\hline \multirow{2}{*}{$\begin{array}{c}\text { Have you had adequate } \\
\text { training on diet counseling? }\end{array}$} & Yes & 136 & 46.8 & \multirow{2}{*}{$\begin{array}{c}145 \pm \\
12.7 \\
\end{array}$} & \multirow{2}{*}{$\begin{array}{c}P<0.0001 \\
\text { HS }\end{array}$} \\
\hline & No & 154 & 53.1 & & \\
\hline \multirow{3}{*}{ Counseling is } & $\begin{array}{l}\text { The two-person situation in which one } \\
\text { person (client) is helped to adjust more } \\
\text { effectively to himself }\end{array}$ & 70 & 24.1 & \multirow[t]{3}{*}{$\begin{array}{l}96.6 \\
\pm \\
69.9\end{array}$} & \multirow[t]{3}{*}{$\begin{array}{c}P<0.0001 \\
\text { SS }\end{array}$} \\
\hline & Offer an opinion or suggestion & 176 & 60.6 & & \\
\hline & Synonymous with consulting & 44 & 15.1 & & \\
\hline \multirow{4}{*}{$\begin{array}{l}\text { Arch criminal in caries } \\
\text { causation is............. }\end{array}$} & Glucose & 67 & 23.1 & \multirow{4}{*}{$\begin{array}{l}72.5 \\
\pm \\
64.9\end{array}$} & \multirow{4}{*}{$\begin{array}{c}P<0.0001 \\
\text { SS }\end{array}$} \\
\hline & Sucrose & 163 & 56.2 & & \\
\hline & Fructose & 50 & 17.2 & & \\
\hline & Xylitol & 10 & 3.4 & & \\
\hline \multirow{3}{*}{$\begin{array}{l}\text { Most beneficial form of food in } \\
\text { preventing caries }\end{array}$} & Sticky & 137 & 47.2 & \multirow{3}{*}{$\begin{array}{c}96.6 \\
\pm \\
37.8\end{array}$} & \multirow{3}{*}{$\begin{array}{c}P<0.0001 \\
\mathrm{SS}\end{array}$} \\
\hline & Fibrous & 91 & 31.3 & & \\
\hline & Refined & 62 & 21.3 & & \\
\hline \multirow{2}{*}{$\begin{array}{l}\text { Food products with regular } \\
\text { sugars can be replaced by } \\
\text { artificial sweeteners. }\end{array}$} & Yes & 206 & 71 & \multirow{2}{*}{$\begin{array}{c}145 \\
\pm \\
86.2\end{array}$} & \multirow{2}{*}{$\begin{array}{c}P<0.093 \\
\text { NS }\end{array}$} \\
\hline & No & 84 & 28.9 & & \\
\hline \multirow{4}{*}{$\begin{array}{l}\text { The most helpful in identifying } \\
\text { Patients who need diet } \\
\text { counseling for the Prevention } \\
\text { of Dental caries is. }\end{array}$} & Oral hygiene index score & 128 & 44.1 & \multirow{4}{*}{$\begin{array}{l}72.5 \\
\pm \\
44.1\end{array}$} & \multirow{4}{*}{$\begin{array}{c}P<0.0001 \\
\text { HS }\end{array}$} \\
\hline & A dental health diet score & 87 & 30 & & \\
\hline & Past medical history & 45 & 15.5 & & \\
\hline & All of the above & 30 & 10.3 & & \\
\hline \multirow{3}{*}{$\begin{array}{c}\text { Dietary counseling } \\
\ldots \ldots \ldots \ldots \ldots \ldots \text { absolute } \\
\text { prevention of Dental caries. }\end{array}$} & Do not guarantee & 174 & 60 & \multirow{3}{*}{$\begin{array}{c}96.6 \\
\pm \\
55.7\end{array}$} & \multirow{3}{*}{$\begin{array}{l}P<0.0001 \\
\text { SS }\end{array}$} \\
\hline & Guarantee & 71 & 24.4 & & \\
\hline & I do not know & 45 & 15.5 & & \\
\hline
\end{tabular}

NS: Not significant; S: Significant; HS: Highly significant

Table-3: Distribution on of study subjects according to their attitudes toward Diet Counseling (n=290)

\begin{tabular}{|c|c|c|c|c|c|c|c|}
\hline \multicolumn{8}{|c|}{ Individual Scenario } \\
\hline Statements & $\begin{array}{c}\text { Strongly } \\
\text { disagree }(\%)\end{array}$ & $\begin{array}{c}\text { Disagree } \\
(\%)\end{array}$ & $\begin{array}{c}\text { Uncertain } \\
(\%)\end{array}$ & $\begin{array}{l}\text { Agree } \\
(\%)\end{array}$ & $\begin{array}{c}\text { Strongly } \\
\text { agree }(\%)\end{array}$ & SD & p-value \\
\hline $\begin{array}{c}\text { Do you think diet counseling should } \\
\text { be emphasized in the dental } \\
\text { curriculum? }\end{array}$ & $\begin{array}{c}66 \\
(22.7)\end{array}$ & $38(13.1)$ & $\begin{array}{c}58 \\
(20)\end{array}$ & $\begin{array}{c}44 \\
(15.1)\end{array}$ & $84(28.9)$ & $\begin{array}{l}58 \pm \\
18.2\end{array}$ & $\begin{array}{l}p<0.0001 \\
\text { HS }\end{array}$ \\
\hline $\begin{array}{l}\text { Proper nutrition is essential to Dental } \\
\text { health. }\end{array}$ & $\begin{array}{c}70 \\
(24.0) \\
\end{array}$ & $27(9.3)$ & $\begin{array}{c}30 \\
(10.3) \\
\end{array}$ & $\begin{array}{c}73 \\
(25.1) \\
\end{array}$ & $\begin{array}{c}90 \\
(31) \\
\end{array}$ & $\begin{array}{l}58 \pm \\
28.0 \\
\end{array}$ & $\begin{array}{c}p<0.0001 \\
\text { HS }\end{array}$ \\
\hline $\begin{array}{l}\text { Improving and maintaining the health } \\
\text { of the mouth is not in your control }\end{array}$ & $\begin{array}{c}98 \\
(33.7)\end{array}$ & $35(12)$ & $\begin{array}{c}71 \\
(24.4)\end{array}$ & $\begin{array}{c}49 \\
(16.8) \\
\end{array}$ & $37(12.7)$ & $\begin{array}{l}58 \pm \\
26.7\end{array}$ & $\begin{array}{c}p<0.0001 \\
\text { HS }\end{array}$ \\
\hline $\begin{array}{l}\text { Incorporating Diet counseling in the } \\
\text { routine Dental practice is important }\end{array}$ & $\begin{array}{c}33 \\
(11.3) \\
\end{array}$ & $72(24.8)$ & $\begin{array}{c}58 \\
(20) \\
\end{array}$ & $\begin{array}{c}40 \\
(13.7) \\
\end{array}$ & $\begin{array}{c}87 \\
(30)\end{array}$ & $\begin{array}{l}58 \pm \\
22.2 \\
\end{array}$ & $\begin{array}{c}p<0.0001 \\
\text { HS }\end{array}$ \\
\hline $\begin{array}{l}\text { Maintaining a healthy mouth is an } \\
\text { individual responsibility. }\end{array}$ & $\begin{array}{c}97 \\
(33.4)\end{array}$ & $42(14.4)$ & $\begin{array}{c}57 \\
(19.6)\end{array}$ & $\begin{array}{c}67 \\
(23.1) \\
\end{array}$ & $\begin{array}{l}27 \\
(9.3) \\
\end{array}$ & $\begin{array}{l}58 \pm \\
26.5\end{array}$ & $\begin{array}{c}p<0.0001 \\
\text { HS }\end{array}$ \\
\hline $\begin{array}{c}\text { The advice of a Registered Dietician } \\
\text { or Nutritionist can be beneficial to a } \\
\text { dentist in planning nutrition } \\
\text { education for his/her patients. }\end{array}$ & $\begin{array}{c}34 \\
(11.7)\end{array}$ & $79(27.2)$ & $\begin{array}{c}53 \\
(18.2)\end{array}$ & $\begin{array}{c}95 \\
(32.7)\end{array}$ & $\begin{array}{c}29 \\
(10)\end{array}$ & $\begin{array}{l}58 \pm \\
28.5\end{array}$ & $\begin{array}{c}p<0.0001 \\
\text { HS }\end{array}$ \\
\hline $\begin{array}{l}\text { The Dentists should refer patients } \\
\text { with physical signs of malnutrition to } \\
\text { a Physician. }\end{array}$ & $\begin{array}{c}33 \\
(11.3)\end{array}$ & $47(16.2)$ & $\begin{array}{c}95 \\
(32.7)\end{array}$ & $\begin{array}{c}73 \\
(25.1)\end{array}$ & $42(14.4)$ & $\begin{array}{c}58 \pm \\
25.4\end{array}$ & $\begin{array}{c}p<0.0001 \\
\text { HS }\end{array}$ \\
\hline Total attitude score & \multicolumn{7}{|c|}{$\begin{array}{c}\text { Favorable: } 21.1 \% \\
\text { Moderate: } 19.4 \% \\
\text { Unfavorable: } 20.7 \%\end{array}$} \\
\hline
\end{tabular}

HS: Highly significant 
K. Srinivasan; Saudi J Oral Dent Res, Feb 2020; 5(2): 99-105

Table-4: Distribution of study subjects according to practice concerning Diet Counseling $(\mathrm{n}=290)$

\begin{tabular}{|c|c|c|c|c|c|}
\hline \multicolumn{6}{|c|}{ Individual Scenario } \\
\hline Variables & Respondents & $\begin{array}{c}\text { Frequency } \\
\text { (n) }\end{array}$ & $\begin{array}{l}\text { Response } \\
\text { Rate }(\%)\end{array}$ & Mean \pm SD & p-value \\
\hline \multirow{5}{*}{$\begin{array}{l}\text { Do you counsel your patients carrying a } \\
\text { high risk for Dental caries? }\end{array}$} & Never & 26 & 8.96 & \multirow{5}{*}{$\begin{array}{c}58 \\
\pm \\
45.4\end{array}$} & \multirow{5}{*}{$\begin{array}{c}p \\
<0.0001 \\
\mathrm{HS}\end{array}$} \\
\hline & Rarely & 15 & 5.1 & & \\
\hline & Sometimes & 129 & 44.4 & & \\
\hline & Often & 73 & 25.1 & & \\
\hline & Always & 47 & 16.2 & & \\
\hline \multirow{5}{*}{$\begin{array}{l}\text { Do you give dietary advice to your } \\
\text { patients? }\end{array}$} & Never & 28 & 9.6 & \multirow{5}{*}{$\begin{array}{c}58 \\
\pm \\
42.9\end{array}$} & \multirow{5}{*}{$\begin{array}{c}p \\
<0.0001 \\
\text { HS }\end{array}$} \\
\hline & Rarely & 54 & 18.6 & & \\
\hline & Sometimes & 119 & 41 & & \\
\hline & Often & 79 & 27.2 & & \\
\hline & Always & 10 & 3.4 & & \\
\hline \multirow{5}{*}{$\begin{array}{l}\text { Do you prescribe dietary supplements } \\
\text { for the prevention of Dental caries? }\end{array}$} & Never & 27 & 9.3 & \multirow{5}{*}{$\begin{array}{c}58 \\
\pm \\
35.6\end{array}$} & \multirow{5}{*}{$\begin{array}{c}p \\
<0.0001 \\
\mathrm{HS}\end{array}$} \\
\hline & Rarely & 41 & 14.1 & & \\
\hline & Sometimes & 105 & 36.2 & & \\
\hline & Often & 87 & 30 & & \\
\hline & Always & 30 & 10.3 & & \\
\hline \multirow{5}{*}{$\begin{array}{l}\text { Do you record the diet history in your } \\
\text { clinical practice? }\end{array}$} & Never & 21 & 7.2 & \multirow{5}{*}{$\begin{array}{c}58 \\
\pm \\
43.3\end{array}$} & \multirow{5}{*}{$\begin{array}{c}p \\
<0.0001 \\
\text { HS }\end{array}$} \\
\hline & Rarely & 11 & 3.7 & & \\
\hline & Sometimes & 113 & 38.9 & & \\
\hline & Often & 88 & 30.3 & & \\
\hline & Always & 57 & 19.6 & & \\
\hline \multirow{5}{*}{$\begin{array}{c}\text { do you refer your patients to a Dietician } \\
\text { or a Nutritionist if needed? }\end{array}$} & Never & 12 & 4.1 & \multirow{5}{*}{$\begin{array}{c}58 \\
\pm \\
42.8\end{array}$} & \multirow{5}{*}{$\begin{array}{c}p \\
<0.0001 \\
\mathrm{HS}\end{array}$} \\
\hline & Rarely & 44 & 15.1 & & \\
\hline & Sometimes & 110 & 37.9 & & \\
\hline & Often & 96 & 33.1 & & \\
\hline & Always & 28 & 9.6 & & \\
\hline \multirow{5}{*}{$\begin{array}{l}\text { How frequently do you give your } \\
\text { patient Diet counseling? }\end{array}$} & Never & 22 & 7.5 & \multirow{5}{*}{$\begin{array}{c}58 \\
\pm \\
38.4\end{array}$} & \multirow{5}{*}{$\begin{array}{c}p \\
<0.0001 \\
\mathrm{HS}\end{array}$} \\
\hline & Rarely & 79 & 27.2 & & \\
\hline & Sometimes & 84 & 28.9 & & \\
\hline & Often & 94 & 32.4 & & \\
\hline & Always & 11 & 3.7 & & \\
\hline \multirow{5}{*}{$\begin{array}{l}\text { Patient compliance is a constraint for } \\
\text { Diet counseling. }\end{array}$} & Never & 23 & 7.9 & \multirow{5}{*}{$\begin{array}{c}58 \\
\pm \\
34.1\end{array}$} & $p$ \\
\hline & Rarely & 87 & 30.0 & & $<0.0001$ \\
\hline & Sometimes & 99 & 34.1 & & \\
\hline & Often & 53 & 18.2 & & \\
\hline & Always & 28 & 9.6 & & \\
\hline Reimbursement is a constraint for Diet & Never & 25 & 8.6 & 58 & \\
\hline counseling. & Rarely & 59 & 20.3 & \pm & $<0.0001$ \\
\hline & Sometimes & 76 & 33.1 & 29.3 & HS \\
\hline & Often & 96 & 26.2 & & \\
\hline & Always & 34 & 11.7 & & \\
\hline Time is a constraint for Diet & Never & 32 & 11.0 & 58 & $p$ \\
\hline counseling. & Rarely & 74 & 27.2 & \pm & $<0.0001$ \\
\hline & Sometimes & 79 & 25.5 & 26.1 & HS \\
\hline & Often & 78 & 26.8 & & \\
\hline & Always & 27 & 9.3 & & \\
\hline Do you have enough confidence in & Yes & 116 & 40 & 58 & $p$ \\
\hline counseling a patient? & No & 58 & 20 & \pm & $<0.0001$ \\
\hline & Not sure & 116 & 40 & 33.4 & HS \\
\hline
\end{tabular}

NS: Not significant; SS: Significant; HS: Highly significant 


\section{DISCUSSION}

The current study set to evaluate the knowledge, attitude, and practice (KAP) on diet counseling among dental practitioners.

Nutrients are substances that the body needs for growth and metabolism. The human body processes over 45 different nutrients from dietary intake necessary for growth, maintenance, and repair at cellular levels [8].

A condition known as malnutrition may develop when the body does not get the right amount of variety of nutrients it needs to maintain healthy tissue and organ function. Malnutrition can occur at any point during an individual's lifetime as a result of poor nutrition or dietary intake [9].

The primary focus of dentistry today, and especially of the future, is the prevention of dental disease, and one of the components of preventive dental care is nutrition [10].

Optimal growth and development are the primary objectives of pediatric nutrition. A child's diet, defined as the combination of foods consumed and the nutrients contained therein, has the profound ability to influence cognition, behavior, and emotional development in addition to ultimate physical growth and development [6].

Food is merely a vehicle for nutrient delivery; the nutrients provide energy for growth, serve as structural components, and participate in all metabolic functions of the body. Food, however, is more than just nutrients: sensory, emotional, social and cultural associations influence food choices [11].

Carole et al., in whose study dental students expressed a generally favorable attitude toward nutrition, and nutritional counseling of their patient's similar findings was reported in the present study [12].

Counseling components shown to increase dietary changes include a comprehensive nutritional assessment, family involvement, social support, group counseling, food interaction (cooking and taste testing), goal setting, and advice appropriate to patient groups and anticipatory guidance [13].

Moynihan PJ noted that most of the study participants $(92.8 \%)$ considered dietary counseling to be an integral part of routine dental practice. This was per the present study [14].

Rajesh Nidhi K. R. et al. had recommended nutritional supplements to their patients, half of the study participants $(47.9 \%)$ said that they practice the same as and when needed. This finding was statistically significant with the present study [15].
When the participants were asked regarding the cariogenicity of different types of sugar, it was seen that considerably small amount of the study participants $(29.7 \%)$ knew that polysaccharides were least cariogenic, around $63 \%$ had answered according to study by Rajesh Nidhi K. R. et al. and this finding was statistically significant with the present study [15].

\section{CONCLUSION}

The dental professional should screen patients to determine nutrition risk and integrate the findings in the treatment plan. With today's emphasis on the prevention of diseases, diet counseling helps to reduce the risk of some illness by appropriate counseling.

\section{SIGNIFICANCE OF THE STUDY}

The information gained from this research could result in improved dietary screening and nutritional counseling practices by the dentist and, subsequently, improvement of oral health in their patients.

\section{LIMITATIONS}

a) The literature search shows minimal studies in this arena, and to the best of our knowledge, this is the first of its kind. Hence, comparisons with previous studies were limited.

b) The participants in this study may not be a representative sample of the population.

c) The results of this study may not be transferrable to dental practicing in settings other than general Dentists offices.

d) The results were based on self-reported responses, and the chances of bias due to under or overreporting cannot be excluded

e) This study was limited to fewer dental practitioners.

\section{RECOMMENDATIONS}

a) Extensive diet counseling beyond the realm of the dental practice is referred to as a medical doctor and a registered dietician.

b) Given the time-consuming nature of diet counseling and the absence of professional nutritionists/dietitians, it was suggested that patients should be referred to trained dental hygienists for diet counseling.

c) The challenge is to make nutrition, dietary assessment, and guidance an integral part of routine dental practice.

d) The impact of nutrition on dental education and clinical practice has created a greater awareness of the need for mainstream dentistry to form liaisons with other professionals in the health care delivery system. 


\section{REFERENCE}

1. Academy of Nutrition and Dietetics. (2013). Position of the Academy of Nutrition and Dietetics: Oral health and nutrition. Journal of the Academy of Nutrition and Dietetics. 1(13):693-701.

2. Sheiham, A., \& Watt, R.G. (2000). The common risk factors approach-A rational basis for promoting oral health. Community Dentistry and Oral Epidemiology; 28: 399-406.

3. Konig, Klaus, G. (2000). Diet, and oral health. International Dental Journal, 50:162-174.

4. Student-Pavlovich, D., \& Elliott, Margaret, A. (2001). Eating disorders in women's oral health. Dental Clinics of North America, 45:491-511.

5. Nizel, P. (1989). Nutrition in clinical dentistry, $3^{\text {rd }}$ edition P: 277-307 WB Saunders and company.

6. Laura, M. (2003). Romito - Nutrition and Oral Health. Dental clinics of North America. 47(2):187-207, 279-303.

7. Dietary, G. (2011). National Institute of Nutrition. ${ }^{\text {2nd }}$ Edition.

8. Nowak, A.J. (1997). The rationale for the timing of the first oral evaluation. Paediatr Dent. 19: 8-11.

9. Sheetal, A., Hiremath, V., Patil, A., Sajjan, Setty, S., \& Kumar, R. S. (2013). Malnutrition and its oral outcome- a review. Journal of Clinical and Diagnostic Research. 7(1):178-180.

10. Council on Dental Health and Health Planning: Suggestions for dietary assessment.(1983). J Am Dent Assoc. 107:78.

11. Kelder, S.H., Perry, C.L., Klepp, K.I., Lytle, L.L. (1994). Longitudinal tracking of adolescent smoking, physical activity, and food choice behaviors. Am J Public Health. 84: 1121-1126.

12. Pietz Carole, L., Fryer, B.A., Fryer, H.C.(1980). Nutritional knowledge and attitudes of dental students. J Am Dent Assoc, 100:366-9.

13. Pignone, M.P., Ammerman, A., Fernandez, L., Orleans, C.T., Pender, N., \& Woolf, S. (2003). Counseling to promote a healthy diet in adults: A summary of the evidence for the U.S. Preventive services task force. Am J Prev Med. 24:75-92?

14. Moynihan, P.J. (2000). Dietary advice in dental practice. Br Dent J. 193:563-8.

15. Rajesh, Nidhi, K. R. (2019). Mahesh Ramakrishnan. Knowledge, attitude, and practices regarding diet counseling among dental undergraduate students. Drug Invention Today. 12(6):1290-93. 